\title{
katG (SER 315 THR) Gene Mutation in Isoniazid Resistant Mycobacterium tuberculosis
}

\author{
Marahatta SB, ${ }^{1}$ Gautam S, ${ }^{2}$ Dhital S, ${ }^{2}$ Pote N, ${ }^{2}$ Jha AK, ${ }^{2}$ Mahato $\mathrm{R},{ }^{1}$ Mishra S, ${ }^{3}$ Poudel BH, ${ }^{4}$ \\ Ramasoota $\mathrm{P}^{5}$ Kaewkungwal J, ${ }^{6}$ Singhasivanon $\mathrm{P}^{6}$
}

\author{
${ }^{1}$ Department of Community Medicine, Kathmandu \\ University School of Medical Sciences University, \\ Nepal \\ ${ }^{2}$ Department of Laboratory Medicine, Nobel College, \\ Pokhara University, Kathmandu, Nepal \\ ${ }^{3}$ Department of Microbiology, Institute of Medicine, \\ Tribhuvan University, Kathmandu, Nepal \\ ${ }^{4}$ Department of Biotechnology Tribhuvan University \\ Kathmandu Nepal \\ ${ }^{5}$ Department of Social and Environmental Medicine, \\ Faculty of Tropical Medicine Mahidol University, \\ Thailand \\ ${ }^{6}$ Department of Tropical Hygiene, Faculty of Tropical \\ Medicine Mahidol University, Thailand
}

\section{Corresponding Author}

Sujan Babu Marahatta

Department of Community Medicine,

Kathmandu University School of Medical Sciences,

Dhulikhel Hospital, Kavre, Nepal

Email: sujanmarahatta@gmail.com

\section{Citation}

Marahatta SB, Gautam S, Dhital S, Pote N, Jha AK, Mahato R, Mishra S, Poudel BH, Ramasoota P, Kaewkungwal J, Singhasivanon P. katG (SER 315 THR) Gene Mutation in isoniazid resistant Mycobacterium tuberculosis. Kathmandu Univ Med J 2011;33(1)1923.

\begin{abstract}
Background

Isoniazid (INH) together with Rifampicin (RFP) forms the cornerstone of a short chemotherapy course for tuberculosis (TB) treatment. Mutation at codon 315 of katG gene is most prevalent in isoniazid resistant Mycobacterium tuberculosis (MTB) and is high in area with high TB incidence. Polymerase Chain Reaction Restriction Fragment Length Polymorphism (PCR-RFLP) has been found to be a reliable and effective tool for the identification of the specific gene alteration.
\end{abstract}

\section{Objective}

The objective of this study was to screen Ser315Thr mutation of KatG gene of INH resistant MTB strain by PCR-RFLP technique.

\section{Methods}

Altogether $37 \mathrm{INH}^{\mathrm{r}}$ MTB isolates obtained from German Nepal Tuberculosis Project (GENETUP) Kathmandu Nepal was included in the study. Deoxyribonucleic Acid (DNA) extraction was performed according to protocol of SORPOCLEAN ${ }^{\mathrm{TM}}$ from the culture isolates. Amplification of the fragment with katG codon 315 was performed in a Biometra Thermocycler using primers. The amplified fragment was cleaved with $\mathrm{Mspl}$. The restriction fragments obtained were electrophoresed in a $2 \%$ agarose gel and were visualized using transilluminator.

\section{Results}

The katG Ser315Thr mutation was observed in 23 (62.2\%) out of 37 INH resistant isolates. The drug susceptibility profile of $\mathrm{INH}^{\mathrm{r}}$ MTB isolates showed all isolates to be resistant to INH and RFP whereas 26 and 27 MTB isolates were resistant to Ethambutol (EMB) and Streptomycin (S) respectively. Seventeen (17) patients were harbouring katG gene mutated strain among Ethambutol and Streptomycin resistant cases.

\section{Conclusion}

The study identified high prevalence of Ser315Thr mutation in katG. The isolates harbouring this mutation were also simultaneously resistant to RFP. Ser315Th could be a potential genetic marker for predicting MDR-TB.

\section{KEY WORDS}

Isoniazid resistant MTB, katG gene, Mycobacterium tuberculosis, PCR-RFLP, mutation.

\section{INTRODUCTION}

Tuberculosis (TB) is the leading cause of mortality and accounts for $26 \%$ of all preventable adult deaths globally. ${ }^{1}$ According to WHO, 8 million cases of TB occur each year, resulting in 3 million deaths. In addition overall one third of worlds' population is currently infected with the TB bacillus, $5-10 \%$ becoming sick at sometime during their lifetime. ${ }^{2}$

Currently TB is treated with an initial two month regimen comprising multiple antibiotics- isoniazid, rifampicin, pyrizinamide and ethambutol (HRZE) to ensure that the mutants resistant to even a single drug do not emerge. In next four months only isoniazid and rifampicin are administered to eliminate any persisting tubercle bacilli. ${ }^{3}$ Isoniazid (INH) together with Rifampicin (RFP) forms the cornerstone of a short chemotherapy course for tuberculosis treatment. Mutation at codon 315 of katG gene is most prevalent in isoniazid resistant Mycobacterium tuberculosis (MTB) and is high in area with high TB 
incidence. The prevalence of mutations at codon 315 varies greatly in different geographical regions. ${ }^{4}$ The prevalence of the katG (AGC ACC) mutation among MDR-MTB strains in the world, varies, being low in area with low TB incidence and high in area with high TB incidence. ${ }^{5}$ China and India carry almost $50 \%$ of worlds MDR-TB burden. ${ }^{6}$ Nepal, being geographically situated between these two nations with open border with India cannot be undermined for upcoming alarming situation of MDR-TB epidemics. Thus, detection of mutation in katG gene in Nepalese strains finds its rationale. The magnitude and trends in MDR tuberculosis are epidemiologically important to monitor, the estimation of the burden of disease is programmatically relevant in shaping policies for screening and treatment. The objective of this study was to screen Ser315Thr mutation of KatG gene of INH resistant MTB strain by PCR-RFLP technique.

\section{METHODS}

A total of 37 strains recovered from different adult patients (age range from 15 to 68 years) were studied. These patients originated either from Lalgadh hospital, Janakpur; Birjung Medical College, Birjung; GENETUP, Kathmandu and National Tuberculosis Centre, Bhaktapur. In Nepal, German Nepal Tuberculosis Project (GENETUP) is the national reference centre for drug susceptibility testing for mycobacteria, and receives all specimens detected in the country as a whole. Clinically and epidemiologically relevant information from each patient was obtained.

\section{DNA Extraction from MTB isolates}

DNA extraction was done as guided by General Protocol for high DNA specimen of SORPOclean ${ }^{\mathrm{TM}}$. A loopful of each bacterial growth on Lowenstein Jensen medium was suspended in $1 \mathrm{ml}$ distilled water, warmed to room temperature $\left(15-20^{\circ} \mathrm{C}\right)$. The $20 \mu \mathrm{l}$ proteinase $\mathrm{K}$ solution $200 \mu \mathrm{l}$ of sample and $200 \mu \mathrm{l}$ of lysis solution was added in $1.5 \mathrm{ml}$ microcentrifuge tube. After vortexing (Taurus Scientifica) for 2-3 min. and incubation $\left(56^{\circ} \mathrm{C} / 10 \mathrm{~min}\right)$, $230 \mu \mathrm{l}$ of $96 \%$ ethanol was added and mixed, and then the mixture was transferred into column. It was then centrifuged in a research centrifuge (REMI Instruments) at $6000 \mathrm{~g}$ for $1 \mathrm{~min}$.Washing was done using Wash solution 1 and Wash solution 2 respectively with $500 \mu$ l each. Finally $100 \mu \mathrm{l}$ of elution buffer pre-warmed at $70^{\circ} \mathrm{C}$ was added to elute purified DNA. The purity of DNA was determined by A260/A280 (optical density of DNA measured at 260 and $280 \mathrm{~nm}$ ) using spectrophotometer (Thermoscientific).

\section{PCR procedure for katG gene amplification}

Amplification of fragment with katG codon 315 was performedinaBiometraThermocyclerwith primers[Operon, Lot\#1188685] katG F (5'AGCTCGTATGGCACCGGAAC3') and katG R (5'AACGGGTCCGGGATGGTG3') in a $25 \mu$ l of a PCR mixture (1 U Taq DNA polymerase; $200 \mu \mathrm{M}$ each dNTP's; $1.5 \mathrm{mM} \mathrm{Mgcl}_{2} ; 15 \mathrm{pmol}$ of each primer; $2.5 \mu \mathrm{l}$ of buffer [Fermentas, lot\#00022114]; 1 $\mu$ l DNA sample) under the following condition (Initial denaturation at $95^{\circ} \mathrm{C} / 10 \mathrm{~min}$; 30 cycles of $94^{\circ} \mathrm{C} / 1 \mathrm{~min} ; 55^{\circ} \mathrm{C} / 1 \mathrm{~min} ; 72^{\circ} \mathrm{C} / 1 \mathrm{~min}$ and a final elongation at $\left.72^{\circ} \mathrm{C} / 4 \mathrm{~min}\right)$. Control reactions for detection of false positive results due to contamination with previously amplified amplicons were performed as follows: a negative control (distilled water) was included in each PCR run; no contamination was detected. A control sample (DNA extracted from INH ${ }^{S}-\mathrm{H} 37 \mathrm{Rv}$; Gene Bank accession no: X68081) was included in each PCR run; it showed clear band at $153 \mathrm{bp}$

\section{Agarose gel electrophoresis}

The amplicons were detected by $2 \%$ agarose gel electrophoresis stained with e ethediul bromide. MTB strain H37Rv and a PCR reaction without MTB DNA were used as positive and negative control in the PCR reaction respectively.

\section{Screening of mutation by RFLP}

PCR amplicons were digested by Mspl (Fermentas, lot no\# ER 0541) incubating the mixture containing $10 \mu \mathrm{l} P C R$ product; $17.0 \mu \mathrm{lNF}$; $2 \mu \mathrm{l} 10 \mathrm{x}$ buffer tango (Fermentas, lot no\# 00033251 ) and $1.0 \mu \mathrm{l} \mathrm{Mspl,}$ at $37^{\circ} \mathrm{C} / 3$ hours. The mutation AGC (Ser) to ACC(Thr) creates an additional Mspl site (CCGG) and thus can be detected by use of this restriction endonuclease As a result, the longest RFLP product obtained was $132 \mathrm{bp}$ for $\mathrm{INH}^{\mathrm{r}}$ isolates with mutated 315 ACC allele and 153bp for katG codon 315 wild type or differently mutated allele. The digested products were detected by $2 \%$ agarose gel electrophoresis stained with ethediul bromide. MTB strain H37Rv, wild type was used as a control in the digestion.

These indicative bands could be clearly discriminated in $2 \%$ agarose gel electrophoresis; they were the only visible bands, while 10 to 21 bp bands ran out of gel and were not considered. The electrophoresis was performed as described above.

\section{Data analysis}

Data were analyzed manually as well as using SPSS Version 16 and findings were interpreted according to frequency distribution and percentage. Data were presented in tables and figures.

Ethical approval for the study was taken from Institutional Review Board Kathmandu University School of Medical Sciences Dhulikhel Nepal. 


\section{RESULTS}

Using the katG primers, amplicons were detected in 37 isolates. RFLP analysis of 37 katG gene showed Ser315Thr mutation in 23 (62.2\%) MTB strains. The RFLP pattern for isolates is shown in figure 1.

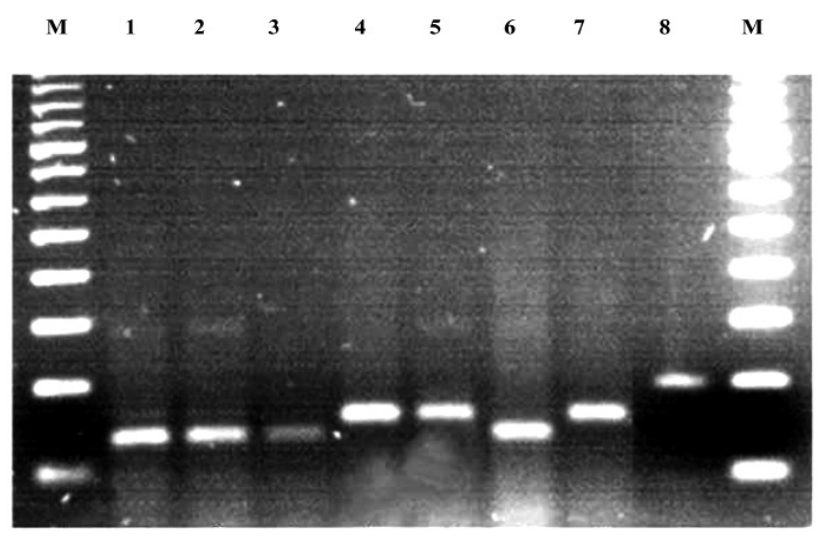

Figure 1.Gel electrophoresis of amplified katG fragment and the products of its digestion

The figure shows that the Lanes 1, 2, 3 and 6, are products obtained by $\mathrm{Mspl}$ digestion of katG gene of $\mathrm{INH}^{\mathrm{r}}$ strains with mutated katG (315ACC); 4, 5 and 7, are products obtained by Mspl digestion of katG strain with wild type or differently mutated strain; lane 8 is the undigested amplified 200bp katG fragment; $M$ represents the 100 base pair DNA ladder (SORPO. Lot no\# 00018146). A total of 37 randomly selected $\mathrm{INH}^{\mathrm{r}}$ isolates were examined.

Table 1. Sex-wise distribution of mutation

\begin{tabular}{llll} 
Case & Male & Female & Total \\
\hline Mutation & 18 & 5 & 23 \\
Wild Type or differently mutated & 7 & 7 & 14 \\
Total & 25 & 12 & 37
\end{tabular}

As per sex-wise distribution, the male patients outnumbered females. Among 25 male subjects 18 (72\%) were harbouring mutated strain of MTB and $7(28 \%)$ were harbouring wild type or differently mutated strain. Among 12 female subjects 5 (41.6\%) were harbouring mutated strain of MTB and $7(58.4 \%)$ were harbouring wild type or differently mutated strain as shown in table 1.

As per resistance pattern of other first line drugs among MDR-MTB isolates with katG gene mutated and Wild type (WT) or differently mutated cases. 17 (73.9\%) each were found to harbor cross-resistance with ethambutol and streptomycin.

As depicted in Table 2, the drug susceptibility profile of MDR-MTB isolates showed that poly-drug resistance pattern predominated with $62.1 \%$ being resistant to HRSE; 13.5\% with HRS and $5.4 \%$ with HRE. However, no monodrug resistant to either $\mathrm{H}$ or $\mathrm{R}$ was observed. The highest no. of katG mutation was found in HRSE resistant strains.
Table 2. Drug Susceptibility Profile of MDR- MTB isolate

\begin{tabular}{lccc|}
$\begin{array}{l}\text { Drug } \\
\text { Resistant Profile }\end{array}$ & $n$ & Mutation & $\begin{array}{r}\text { PCR-RFL study } \\
\text { Wild Type or differ- } \\
\text { ently mutated }\end{array}$ \\
\hline H & 0 & 0 & 0 \\
HR & 7 & 4 & 3 \\
HRE & 2 & 2 & 0 \\
HRS & 5 & 2 & 3 \\
HRSE & 23 & 15 & 8 \\
Total & 37 & 23 & 14 \\
\hline
\end{tabular}

H: Isoniazid; R: Rifampicin; E: Ethambutol; S: Streptomycin.

Table 3. Resistance Pattern of $\mathbf{1}^{\text {st }}$ line Drugs

\begin{tabular}{lllll} 
Drugs & Isoniazide & Rifampicin & Ethambutol & Streptomycin \\
$\begin{array}{l}\text { Patient with } \\
\text { mutated }\end{array}$ & 23 & 23 & 17 & 17 \\
strain & & & & \\
\hline
\end{tabular}

\section{DISCUSSION}

Multidrug resistant tuberculosis is entirely a man made phenomenon $^{3}$ but not due to emergence of novel resistance mechanism ${ }^{7}$; whereby MTB bacilli acquire resistant to at least isoniazid and rifampicin. ${ }^{3}$ The ability of DOTS programs to reduce transmission and incidence of both drug susceptible and drug- resistant tuberculosis is debatable; while some studies have shown successful reduction of drug resistance under WHO strategy, others have demonstrated an "amplifier effect" of increasing drug resistance under DOTS- prescribed short course therapy. ${ }^{8}$

The most frequent mutation patterns of isoniazid, rifampicin and streptomycin resistant strain occurred at codon 315 (55-90\%) of katG; codon 531 (40-60\%) and codon526 (10-30\%) within RPF resistance determining region of rpoB; and codon 43 (47-79\%) of rpsL within Streptomycin resistant MTB. Mutation in katG gene occurs in a 100 fold higher frequency than $r p o B$ gene ${ }^{9}$ and is regarded as first step in evolution of MDR-MTB ${ }^{10-13}$ and also creates more possibility for acquiring mutations in other genes. ${ }^{13-15}$ The combination of INH resistance and maintained virulence might make it possible for some INH resistant strains, especially those with the katG Ser315Thr mutation, to acquire extra drug resistance and become MDR-TB. ${ }^{13}$ The molecular basis of resistance to isoniazid is more complex and is caused by a variety of mutations in four different genes of MTB i.e. katG encoding catalase peroxidase, inhA encoding the enoyl acyl carrier protein (ACP) reductase, kasA encoding $\beta$-ketoacyl ACP synthase and ahpC encoding alkyl-hydroperoxide reductase e.t.c. Even then, nearly $5-10 \%$ of isoniazid-resistant $M$. tuberculosis isolates do not have an identifiable mutation. ${ }^{16}$ 
This study was conducted to gain further insight into molecular basis of $\mathrm{INH}^{\mathrm{r}}$ MTB circulating in Central development region of Nepal. We found that mutation in katG gene (Ser315Thr substitution) was responsible for $62.2 \%$ of $\mathrm{INH}^{\mathrm{r}}$ strains. We compared our result of mutation at katG codon 315 associated with INH resistance and results of demographic findings with those of earlier studies done worldwide.

The prevalence of katG S315T substitution in MTB strains vary all over the world especially with regard to TB prevalence. ${ }^{17-19}$ In place like Singapore ${ }^{20}$ and Madrid ${ }^{21}$ where prevalence of TB incidence is intermediate and low, mutation has been reported in $26-30 \%$ isolates. In contrast the Ser315Thr mutation accounted for INH resistance in $52-64 \%$ of strains in Central Africa. ${ }^{22-23}$ Several studies have revealed that mutation in katG gene is responsible for $60-70 \%$ of $\mathrm{INH}^{\mathrm{r}}$ strains. ${ }^{24} \mathrm{~A}$ study by Negi S.S et al., ${ }^{25}$ in 2006, in India revealed katG S315T mutation in $74.19 \%$ of strains of MTB from Delhi. In Nepal where incidence of all forms of TB is 173 cases per $1,00,000$ population $^{3}$ the Ser315Thr mutation we found was not as high as those of north-western Russia $(93.6 \%)^{26}$ Germany $(86.41 \%)^{28}$ , Lithuania (85.71\%) ${ }^{15}$ but was concordance with other results in Mexico (67.61\%), Poland (66.3\%), and Australia (65.4\%). ${ }^{29}$ Similarly, Wang Y.C et al., ${ }^{18}$ from China reported 68.6\%; Hass W.H ${ }^{30}$ from West Africa reported $60 \%$ of INH strains associated with mutation in katG due to S315T substitution. Our finding of mutation in the katG Ser315Thr substitution (i.e 62.2\%) is similar to those reported in other parts of the world, which reflects a global pattern.

Furthermore, in current study association was conformed between the common katG Ser315Thr mutation in INH resistant strains and the presence of resistance to other first line drugs (i.e. RPF, EMB, and S). These observations might suggest that the INH resistant with katGS315Thr mutation may be more likely to develop resistance to other first line drugs. Hu Yi et al., ${ }^{13}$ in their study also found similar correlation between INH resistance and development of resistance to other first line drugs. Since all the $\mathrm{INH}^{\mathrm{r}}$ isolates were resistant to RPF as well so we concluded that all the strains under study are MDR-MTB isolates.

The present study identified katG Ser315Thr mutation in Nepalese $\mathrm{INH}^{\mathrm{r}}$ isolates, so the results we obtained could not be compared with other local investigations. But extensive transmission of $\mathrm{INH}^{\mathrm{r}}$ MTB was observed in Eastern region of neighbouring country, China. Most INH isolates have strong transmissibility, full virulence and survival advantage even under the drug pressure in the host. ${ }^{13}$ The study conducted in China presented mutation with $68.6 \%{ }^{18}$ cases among INHr MTB strains; India, the next neighbouring country of Nepal presented mutation with $64.3 \%{ }^{30}$ cases among INHr MTB strains. The samples we included were also included from two different areas of eastern terai which has open border with India. Thus, the chance, that Nepal may carry extensive transmission rate of INH'-TB with katG gene mutation cannot be ignored. On the other hand the increased possibility that the INH ${ }^{r}$ MTB with the katG Ser315Thr mutation in the index person is more likely to experience a series of subsequent mutations, leading to the accumulation of MDR and/ or extreme drug resistant(XDR)-TB. ${ }^{31}$

Furthermore, in current study we found number of male patients outnumbering the number of female patients with INH resistant isolates. In a molecular epidemiological study of $\mathrm{Hu}$ Yi et al. $^{13}$ in eastern China similar type of finding was stated where male outnumbered female patients with average age being 30 years. Similarly in his study, Pandey R.P ${ }^{32}$ in Doti district of Western region of Nepal also found male patients outnumbering female patients with average age of male being 36.7 and female being 33.7 suggesting that the prevalence of MDR-TB within the country may vary among different age groups.

Early detection of the patients carrying INH resistant strains would facilitate the modification of treatment regimens and appropriate infection control measures can be taken in time to reduce the risk of further development and transmission of MDR-TB. An understanding on the molecular level of the mechanism of drug resistance in MTB will enable us to develop improved tools. It deserves further investigation to determine which mechanism may play the critical role in the epidemic of MDR-TB, since the implication behind it could be meaningful to evaluate the performance of local TB control as well as to determine the MDR-TB strategies.

\section{CONCLUSION}

The study identified high prevalence of Ser315Thr mutation in katG. The isolates harbouring this mutation were also simultaneously resistant to RFP. Ser315Th could be a potential genetic marker for predicting MDR-TB. The molecular detection of this mutation by PCR-RFLP in TB control programmes could help in early detection, management and containment of MDR-TB cases.

\section{ACKNOWLEDGEMENT}

UNDP/World Bank/WHO Special program for Research and Training in Tropical Disease (TDR) Geneva Switzerland; Nobel College Kathmandu and GENETUP Kathmandu Nepal

\section{REFERENCES}

1. Kramnik I, Dietrich W.F, Demant P, et al. Genetic control of resistance to experimental infection with virulent Mycobacterium tuberculosis. PNAS 2000: 97(15): 8560-5.

2. World Health Organization. Global tuberculosis control: surveillance, planning, financing.WHO report 2008. Geneva, World Health Organization, 2008.

3. National Tuberculosis Programme of Nepal: A clinical manual. National Tuberculosis Center, 2009. 
4. Siqueira de R.H, Freitas de D.A.F, Oliveira de N.D et al. Isoniazidresistant Mycobacterium tuberculosis strains arising from mutations in two different regions of the katG gene. J. bras. pneumol 2009; 35 (8):773-9.

5. Mokrousov I, Otten T, Filipenko $\mathrm{M}$ et al. Detection of IsoniazidResistant Mycobacterium tuberculosis strains by multiple allele specific PCR assay targeting katG codon 315 variation. J. Clin. Microbiology 2002; 40(7): 2509-12.

6. Wright A, Zingol M, Deun A.V et al. Epidemiology of anti-tuberculosis drug resistance 2002-07: an updated analysis of the global project on anti-tuberculosis drug resistance surveillance. The lancet 2009; 373 : 1861-72.

7. Rattan A, Kalia A, Ahmed N. Multi-Drug resistant Mycobacterium tuberculosis: molecular perspectives. Ind.J.Tub 1999; 46: 51-68.

8. Marahatta S.B. Multi-drug resistant tuberculosis burden and risk factors: An update. Kathmandu Univ Med J 2010; 8(1):116-25.

9. Siqueira de R.H, Freitas de D.A.F, Oliveira de N.D et al. Isoniazidresistant Mycobacterium tuberculosis strains arising from mutations in two different regions of the katG gene. J. bras. pneumol 2009; $35(8): 773-9$

10. Jindani A, Aber V.R, Edwards E.A et al. The early bactericidal activity of drugs in patients with pulmonary tuberculosis. Am Rev Respir Di 1980; 121: 939-49.

11. Tracevska T, Jansone I, Broka L et al. Mutations in the rpoB and katG genes leading to Drug resistance in Mycobacterium tuberculosis in Lativa. J.Clin Microbiol 2002: 3789-92.

12. Brimacombe M, Hazbon M, Motiwala A.S et al. Antibiotic resistance and single nucleotide polymorphism cluster grouping type in a mutational sample of resistant $M$. tuberculosis isolates. Antimicrob Agents Chemotherap2007; 51(11): 4157-9.

13. Hu Y, Hoffner S, Weili J et al. Extensive transmission of isoniazid resistant $M$.tuberculosis and its association with increased multidrug resistant TB in two rural countries of eastern China: A molecular epidemiological study. BMC Infectious Diseases 2010; 10 (43).

14. Varela G, Gonzalez S, Gadea P et al. Prevalance and dissemination of the Ser315Thr substitution within the katG enzyme in isoniazidresistant strains of Mycobacterium tuberculosis in Uruguay. Journal of Medical Microbiology 2008; 57: 1518-22.

15. Bakonyte D, Baranauskaite A, Cicenaite J et al. Molecular characterization of isoniazid- resistant Mycobacterium tuberculosis clinical isolates in Lithuania. Antimicrob Agents and Chemother 2003; 47(6): 2009-11.

16. Tripathy S.P. Relapse in tuberculosis. Indian J Tuberc 1981; 28: 45-57.

17. Mokrousov I, Otten T, Filipenko M, et al. Detection of IsoniazidResistant Mycobacterium tuberculosis strains by multiple allele specific PCR assay targeting katG codon 315 variation. J. Clin. Microbiology 2002; 40(7): 2509-12.

18. Wang Y.C, Zhu R.Y, Xu Y.Y, et al. Molecular characterization of drug resistant Mycobacterium tuberculosis isolates in Guangdong, China. Jpn. J. Infect dis 2009; 62: 270-4.
19. Tracevska T, Jansone I, Broka L et al. Mutations in the rpoB and katG genes leading to Drug resistance in Mycobacterium tuberculosis in Lativa. J.Clin Microbiol 2002: 3789-92.

20. Lee A.S.G, Lim I.H.K,Tang L.L.H et al. Contribution of kasA analysis to detection of isoniazid resistant M.tuberculosis in Singapore. Antimicrob Agents Chemother 1999; 43: 2087.

21. Piatek A.S, Telnenti A, Murray M.R et al. Genotypic analysis of M.tuberculosis in two district populations using molecular beacons : Implication for rapid susceptibility testing. Antimicrob Agents Chemotherap 2000; 44: 103-10.

22. Dobner P, Rusch-Gerdes S, Bretzel G et al. Usefulness of M.tuberculosis genomic mutation in the genes katG and inhA for the prediction of isoniazid resistant. Int J Tubercl Lung Dis 1997;1:365.

23. Hass W.H, Schilke K, Brand J et al. Molecular analysis of katG gene mutations in strains of Mycobacterium tuberculosis complex from Africa. Antimicro Agents chemother 1997:1601-3.

24. Aragon L.M, Navarro F, Heiser $V$ et al. Rapid detection of specific gene mutations associated with isoniazid or rifampicin resistance in Mycobacterium tuberculosis clinical isolates using non-fluroscent low density DNA microarrays. Journal of Antimicrobial Chemotherapy 2006; 57:825-83

25. Negi S.S, Anand R, Pasha S.T et al. Molecular characterization of mutation associated with rifampicin and isoniazid resistance in Mycobacterium tuberculosis isolates. Indian Journal of Experimental Biology 2006; 44:547-53.

26. Wang Y.C, Zhu R.Y, Xu Y.Y et al. Molecular characterization of drug resistant Mycobacterium tuberculosis isolates in Guangdong, China. Jpn. J. Infect dis. 2009; 62: 270-4.

27. Hillemann D, Rusch-Gerdes S, Richter E. Evaluation of genotype MTBDRplus assay for rifampin and isoniazid susceptibility testing of M. tuberculosis strains and clinical specimens. Journal of Clinical Microbiology 2007; 45; 8: 2635-40.

28. Ramaswamy S.V, Dou S, Rendon A et al. Genotypic analysis of multidrug-resistant Mycobacterium tuberculosis isolates from Monterrey, Mexico. Journal of Medical Microbiology 2004; 53:10713.

29. Hass W.H, Schilke K, Brand J et al. Molecular analysis of katG gene mutations in strains of Mycobacterium tuberculosis complex from Africa. Antimicro Agents chemother 1997:1601-3.

30. Unissa A.N, Selvakumar N, Narayanan A et al. Molecular analysis of isoniazid resistant clinical isolates of Mycobacterium tuberculosis from India. International Journal of Antimicrobial Agents 2008; 31:71-

31. Ano $H$, Matsumoto $T$, Suetake $T$ et al. Relationship between the isoniazid-resistant mutation katG S315T and the prevalence of MDR-/ XDR-TB in Osaka, Japan. Int J Tuberc Lung Dis 2008; 12:1300-5

32. Pandey J.N, Singh U.B, Sinha S. et al. Evaluation of risk factors and prevalence of drug resistant tuberculosis in North India. Chest 2002; 128(4): 404-8. 